\title{
A CRITICAL ANALYSIS OF THE FEDERAL-STATE SYSTEM OF UNEMPLOYMENT COMPENSATION
}

\author{
John C. Gali* and R. S. Smethursti
}

In presenting a critical analysis of our federal-state system of unemployment compensation from the viewpoint of employers, it is essential that we disclaim any intention or authority to present the views of all employers in the United States. We purport only to advance criticisms based on principles unanimously adopted by the National Association of Manufacturers, with which we are identified, representing the considered opinion of a real majority of all manufacturers throughout the country. Employers generally, like others, have been divided in their opinion on the desirability of unemployment compensation as a matter of right, rather than on the basis of demonstrated need, and likewise over the form in which any such system should be enacted.

Before enactment of the Federal Social Security Act, employers in manufacturing enterprises represented through our Association, after a careful and extended study of English and other European systems, and of plans proposed for the United States, adopted a resolution reading in part as follows: ${ }^{1}$

"Unemployment growing out of the depression has directed attention to the practicability of dealing with its recurrence through so-called compulsory unemployment insurance, benefits or reserves.

"Industry is ready to coöperate in an adequate and impartial study, and also to give approval to the adoption of a sound solution. The fear of a wrong solution, and the unpredictable effects of such a program, are serious deterrents to forward planning by business, so necessary to recovery.

"Unless corrective measures are founded on adequate knowledge they are almost certain to be injurious rather than beneficial.

"It is generally admitted by advocates of such compulsory unemployment insurance or reserve laws that the federal government cannot constitutionally establish a national system. To overcome this difficulty they propose, however, to provide federal subsidies to state

- LL.B., 1922, George Washington University. Member of the District of Columbia and Virginia Bars. Associate Counsel, National Association of Manufacturers; counsel for various manufacturers' and employers' assaciations. Author of Some Observations on British Experience in the Field of Employment Relations and Social Instrance; contributor to various publications on labor legislation, social security, and other subjects of federal legislation.

† B.S., Harvard University; LL.B., George Washington University. Member of the District of Columbia Bar. Assistant Counsel, National Association of Manufacturers. Contributor to legal periodicals.

12 "Plafform of American Industry" adopted at Annual Convention, National Association of Manufacturers, Dec., 1934. 
unemployment insurance or reserve systems or to make it seem advantageous for the states to establish such systems by imposing discriminatory federal taxes upon employers in states not having such laws.

"We are opposed to a federal system of either character because it would impose national control upon what are primarily local problems, a universal policy over widely varying conditions. Experience under N. I. R. A. codes demonstrates the great difficulty of making any fair application of national standards to the greatly diversified conditions in industries in the several states growing out of difference in size, location, type of operations, and abilities to assume new burdens."

In December, 1935, after enactment of the Federal Social Security Act, and following a careful study of its provisions, further recommendations were unanimously adopted in convention, reading in part that:

"The Federal Social Security Act is contrary to the public interest in that it attempts to force uniform treatment of old age relief, relief of unemployment distress and relief of certain other forms of distress throughout the entire nation, regardless of local circum. stance and environment. It undertakes to accomplish this end by withdrawing from the national income and segregating in reserves such a large proportion of such income as seriously to disrupt current buying power. It thus creates reserves, which must be invested in securities of the Federal Government or guaranteed by it, in so large an amount as to encourage governmental extravagance and a continually expanding government debt. Extremely difficult problems of liquidation will arise when such reserves are required in the future.

"This Act undertakes by the indirect route of taxation to force the respective states to acquiesce in its program, for their own protection, regardless of what may be their considered judgment as to the merits of its objectives.

"These taxes, placed upon both the employee and the employer, will of necessity raise the cost of manufactured products, with a resulting increase in sales prices. This increase in prices, together with the diversion of income into government controlled reserves, will reduce the current buying power of the people and the demand for manufactured goods and employment in industry.

"The Association is further of the opinion that any social security sought for by the individual states through statutory provisions should consider the following viewpoint, generally held by industry:

"(a) Insurance against unemployment of a depressional character is impractical. All that can be hoped for from any form of unemployment insurance that will stand the test of time, is some form of termination compensation.

"(b) Relief of depressional unemployment distress should be given on the basis of need only and not on the basis of statutory right. Such relief should be financed by current general taxation, except in an emergency, when it may be properly financed by temporary expansion of debt to be liquidated by early future taxation."

In presenting our analysis, reflecting the viewpoint of employers, we adopt these expressions as our guide. We approach our task with full realization that the position of the employer with respect to social legislation is easily misunderstood and as readily misinterpreted. Objection to the form of legislation, or to its timeliness, or to any of its details, is translated by many into opposition to its objective. But that is not the attitude of those whose views we present. 
They agree at once that society must, as a matter of self-defense, care for all those persons who for one reason or another have become unwilling victims of any of the great hazards of life and who have no means of livelihood save that provided by society itself. They make no distinction in this respect between old age destitution and that arising from accident, ill health, or unemployment.

But the means by which this objective is to be accomplished, the political and social organizations which have the responsibility for providing the necessary assistance, and the extent of the assistance to be given, are fundamental matters upon which we believe there not only can be, but is, great disagreement among many people who, like employers, are sympathetic with the objective.

With this attitude we undertake our analysis of the system of unemployment compensation inaugurated under Title IX of the Federal Social Security Act. This law imposes a tax on employers and permits credits against that tax for contributions made under state unemployment compensation laws approved by the Federal Social Security Board. The federal law contains certain provisions which must be included in any state law before contributions paid under it can be credited against the federal tax. Provision is also made for a system of additional credit allowances for employers whose contributions under state laws are reduced because of good employment records. These additional credits are allowed only if the state law allowing lower rates of contribution conforms to certain other standards prescribed in the Federal Act.

Federal supervision over the administration of state laws is accomplished through Title III of the Social Security Act, under which federal funds will be donated to the states for administration of their unemployment compensation laws. These grants will be made, however, only when the state laws have been approved under Title IX, and contain certain additional provisions prescribed in Title III relating to administration.

Our major criticisms of the federal-state system of unemployment compensation contemplated by the Federal Social Security Act may be summarized as follows:

I. The Federal Act imposes upon the states, and has itself adopted, one of the most objectionable systems of taxation which could have been selected, from the standpoint of the government and of those who must pay the tax.

2. The Federal Act has denied to the states the privilege of enacting unemployment compensation laws sufficiently flexible to meet diverse local needs and condjtions.

3. Recognizing that the federal government has assumed the function of guiding the states in the enactment of sound unemployment compensation laws, the Social Security Act has failed to impose standards which should have been prescribed to secure a sound and effective federal-state system.

4. The Federal Social Security Act has failed to provide the necessary safeguards 
to insure the creation and maintenance of efficient and non-partisan administrative machinery either for itself or in the several states.

Returning to our first objection, our criticism is directed against the use of a payroll tax, first for the purpose of coercing state legislation, and second, as a sound method for supporting a system of unemployment compensation. The tax is levied upon the act of providing employment. It is imposed without regard to ability to pay, on the theory that the burden of the tax represents a legitimate item in cost of production. It is levied on payrolls in the face of widespread unemployment and at a time when it necessarily operates with peculiar harshness. These objections are on economic and political grounds, but they are supported by a brief consideration of the legal and administrative problems resulting from the use of the payroll tax by the Federal Government itself and by the States upon whom it has been inflicted by the Social Security Act.

The Federal Act imposes upon every employer of eight or more individuals (except in certain excluded employments), a tax beginning at the rate of $x \%$ of total wages payable by the employer during the calendar year $1936,2 \%$ during 1937 , and $3 \%$ thereafter. ${ }^{2}$ Who is an employer subject to the tax? The law provides that an employer does not include any person unless on each of some twenty days during the calendar year, each day being in a different calendar week, the total number of individuals in his employ for some portion of the day was eight or more. ${ }^{3}$ Except in border line cases, perhaps, there should be no great difficulty in determining who is an employer for the purposes of the federal tax. The next question, however, is, to ascertain who should be considered "in his employ" to determine whether he employs eight or more individuals. The term "in his employ" is not defined, but the term "employment" means any service performed within the United States by an employee for his employer, with the exception of certain classes of services excluded from the Act. ${ }^{4}$ By this definition we are again brought to the question of ascertaining who is an "employee." The Federal Act defines an employee only as follows: "The term employee includes an officer of a corporation." 5 There is no further attempt at definition. The tax is levied on total wages payable by the employer with respect to any service performed within the United States for him by an employee. ${ }^{0}$ The term "employee," therefore, is important not only in determining whether the employer has eight or more individuals in his employ, but also in fixing the total wages upon which the federal tax must be paid.

The term "wages" is subject to the same ambiguity. The term is defined to mean "all remuneration for employment, including the cash value of all remuneration paid in any medium other than cash." For a law which purports merely to establish an incentive for state legislation, Title IX of the Social Security Act has probably in-

${ }^{2}$ Social Security Act of Aug. 14, 1935, Public, No. 271, 74th Cong., Ist Sess., tit. IX, \$901.

${ }^{8} I d$. $\$ 907$ (a).

Id. $\$ 907$ (c).

'Id. \$§gor, 907.

'Id. \$IIOI (a) (6).

"Id. $\$ 907$ (b). 
jected more ambiguous phrases into the law, susceptible to varying interpretations, than any previous statute of the kind yet enacted. While for the purposes of administration by the federal government, these ambiguities may be clarified in the form of uniform rules applicable where the federal tax is levied, the same uncertain concepts have been copied in state laws where no uniformity of interpretation can be expected.

We emphasize these ambiguities, not to criticize those who drafted the legislation, but to point out the inherent objections to a payroll tax. It is a tax imposed upon an economic relationship which has escaped legal definition. At common law the relationship of master and servant was marked out under the law of contract and tort. Well established distinctions carried us into the law of principal and agent, or succeeded in creating a new relationship of independent contractor. Under modern statute law, the emphasis has shifted from contract to status, and delineation of the employer-employee relationship has been controlled by the impact of public policy represented in modern legislation. For example, the relationship under workmen's compensation laws and employers' liability acts is defined to relate the employer's liability to the degree of control exercised over the employee or his place of employment. Under more recent legislation pertaining to labor disputes, the relationship of employer and employee is differently defined to effectuate an entirely different public policy. ${ }^{8}$ It is obvious that under unemployment compensation laws, the relationship must be even further defined to reflect the new social responsibility imposed upon employers.

It is unfortunate, therefore, that this elusive and constantly changing legal relationship should have been selected as the subject of a federal tax, with the consequent emphasis on the production of revenue rather than upon establishing a realistic demarcation of its true economic limits. In practice, it means that many efficient and economically desirable methods of doing business must be altered or abandoned to avoid the imposition of tax liability in cases where the employer could not, under any reasonable concept of social obligation, be considered responsible for the future unemployment of persons now performing services for him. ${ }^{9}$

These objections to the federal law are not confined merely to the language which determines the original tax liability of an employer. The same uncertainties have been included in those sections of the Act which permit credits against the federal

"In the National Labor Relations Act, 29 U. S. C. A. (Supp. 1935) \$I52 (3), the term "employee" is defined to continue the "status" of employer-employee even after any contract of employment may have been terminated. It reads: "The term 'employee' shall include any employee, and shall not be limited to the employees of a particular employer, unless the Act explicitly states otherwise, and shall include any individual whose work has ceased as a consequence of, or in connection with, any current labor dispute or because of any unfair labor practice, and who has not obtained any other regular and substantially equivalent employment, but shall not include any individual employed as an agricultural laborer, or in the domestic service of any family or person at his home, or any individual employed by his parent or spouse."

- As an example, compare provisions in state laws already enacted imposing primary liability on persons contracting for supplies for the payment of the tax on payrolls of subcontractors or suppliers. E.g. N. Y. Consol. Laws, c. 31, art. 18 , $\$ 502$ (3) (N. Y. Laws I935, c. 468). 
tax for contributions made under an approved state unemployment compensation law. In the first place, no credit will be allowed against the federal tax unless the state law has been approved by the Federal Social Security Board. To secure original approval, the state law must contain certain provisions specified in the Federal Act. Among other mandatory provisions, the state law must provide that no compensation shall be denied to any eligible individual for refusing to accept new work, if the position offered is vacant due directly to a strike, lockout, or other labor dispute; if the wages, hours or other conditions of the work offered are substantially less favorable to the employee than those prevailing for similar work in the locality, or, if as a condition of being employed the individual would be required to join a company union or to resign from or refrain from joining any bona fide labor organization. $^{10}$ What is a "company union," or even a "bona fide labor organization"? Until the past three years, no attempt has been made by any branch of government to give either legislative or judicial interpretation to these new concepts. ${ }^{11}$ For the same reason, objection should be raised to the use of" the language "strike, lockout, or other labor dispute." Strikes may be legal or illegal and labor disputes may or may not involve any differences between an employer and his own employees. ${ }^{12}$ The effect, however, of including such specifications in the Federal Act is to force upon the states a policy of awarding compensation to former employees who have voluntarily quit their employment pursuant to an illegal strike or because of some jurisdictional or other dispute between rival labor organizations in the establishment. Furthermore, the term "substantially less favorable," relating to wages, hours or other conditions of work is likewise ambiguous. Does this mean that an employee could refuse to accept work in an employment not covered by a state unemployment compensation law or for an employer not subject to the Federal Old-Age Insurance plan? Certainly the loss of future benefits for unemployment or of insurance for old age would result in a condition "substantially less favorable" to the individual. Finally, what comprises "similar work in the locality?"13

In addition to these uncertain conditions upon which original approval must be based, approval of a state law may be withdrawn at any time for reasons over which the taxpayer has no control, and for causes which cannot be anticipated in advance.

${ }^{10}$ Social Security Act, supra note 2, tit. IX, $\$ 903$ (a) (5).

${ }^{21}$ The terms have been used, but not defined, in Scction 7 (a) of the National Industrial Recovery Act, 48 STAT. 198 (1933), 15 U. S. C. A. (Supp.) $\$ 707$ (a), and in the Bankruptey Act, as amended by $\Lambda$ ct of March 3, 1933, 47 STAT. I 48I, II U. S. C. A. (Supp.) \$205 (o)-(q). In the National Labor Relations Act, supra note $8, \$ 152$ (5), the term "company union" was not used, but the term "labor organization" was defined to mean: "Any organization of any kind, or any agency or employee representation committee or plan, in which employees participate and which exists for the purpose, in whole or in part, of dealing with employers concerning grievances, labor disputes, wages, rates of pay, hours of employment, or conditions of work."

${ }^{12}$ See definition of "labor dispute" in National Labor Relations Act, supra note 8, $\$ 152$ (9), and in the Norris-La Guardia Anti-injunction Act, 47 STAr. 70 (r932), 29 U. S. C. A. (Supp.) $\$ 113$.

${ }^{13}$ See Connally v. General Construction Co., 269 U. S. 385 (1926), wherein the Court said, at p. 394: "Additional obscurity is imparted to the statute by the use of the qualifying word 'locality.' Who can say, with any degree of accuracy, what areas constitute the locality where a given piece of work is being done?" 
The law provides that the Board shall not certify that a state law complies with the federal standards if "it no longer contains the provisions specified" in the Social Security Act as now written, or "has with respect to any taxable year failed to comply substantially with any such provision."14

The law also provides that credit may be taken against the federal tax for "the amount of contributions, with respect to employment during the taxable year."15 Presumably, because of the limited definition of "employment" in Title IX of the Federal Act, this means that contributions to a state fund covering employees excluded from the federal law could not be used in claiming credit against the federal tax. However, under Section 909 of the federal law an employer may credit against the tax, contributions which he might have been required to pay if he had been subject to the higher rates prevailing in any particular state. In other words, additional credits apparently are allowed employers entitled to lower rates of contribution even though these contributions are made with respect to employments not covered under the Federal Act.

These so-called additional credit allowances are ambiguous in another respect. The additional credits are allowed to favored employers when contributions actually paid by them are exceeded by contributions they would have been required to pay if their employment record was less meritorious. They are permitted to credit against the federal tax an amount representing the difference between the contributions actually paid and those which they might have paid if they were subject to the higher rates. Does this mean that no state could entirely exempt an employer from any contributions, if a sufficient reserve has been established, without subjecting such employer to the total federal tax? Apparently it precludes any state law permitting private compensation plans or exempting certain classes of employers from paying any contributions whatever. The consequences of such a situation will be discussed elsewhere. ${ }^{10}$

Many of these ambiguities in the federal law could have been avoided. Some, perhaps, can be cured by regulations or even by prompt amendments to the law. Unfortunately, however, they have been reflected in the legislation of several states, and for that reason have created confusion and complications not easily to be corrected. Employers who must bear the burden of clarification have a legitimate basis of criticism.

These objections to language and terminology, although serious enough to impede fair and impartial public administration, may appear relatively unimportant in the light of more fundamental defects which we now consider. We have already mentioned several objectionable features of a tax on payrolls. This form of tax has been universally adopted in state compensation laws already enacted, and the evils of such a tax have been intensified because used to discourage compulsory contributions from those who benefit directly from unemployment compensation. It is our contention

"Social Security Act, supra note 2, tit. IX, \$903 (b).

${ }^{15}$ Id. $\S 902$.

${ }^{16}$ See p. 131, infra. 
that no compulsory system of unemployment compensation based on a "pooled fund" plan can be maintained on a solvent basis, if that system does not require contributions by employees eligible for benefits. There is even considerable force to the British argument for equal contributions by employers, employees and the government. The argument is that if there is a three-way plan of contribution and on an equal basis, each of the three parties is practically estopped to agitate for increases in rates of benefit which may have the effect of breaking down the fund. Employee organizations cannot agitate for these increases because to do so is to advocate additional taxation of the employees. Majority political parties being charged with the responsibility of balancing budgets and maintaining the solvency of the insurance fund are much less likely to make inroads upon the fund when they also have the responsibility of levying taxes to meet possible deficits. By levying a payroll tax on employers, and by permitting credits against that tax only to the extent of contributions to state laws actually paid by employers, the federal law has discouraged the adoption in state laws of the principle of equal joint contributions, or the adoption of any other method of financing unemployment compensation. ${ }^{17}$

A second, and perhaps more serious defect in the Federal Act arises from its failure to permit flexibility in state laws to meet local conditions. On this point, the President's Committee on Economic Security stated the sound principle. It recommended that: ${ }^{18}$

"The plan for unemployment compensation that we suggest contemplates that the States shall have broad freedom to set up the type of unemployment compensation they wish. We believe that all matters in which uniformity is not absolutely essential should be left to the States."

Its detailed recommendations, however, did not conform to this declaration, and a study of state compensation laws thus far enacted will reveal that flexibility has been permitted by the federal law in name only. Flexibility connotes that the individual states should be permitted to adopt legislation based on local needs and conditions, dependent upon the extent of industrial development and the nature of the unemployment problem in particular trades or industries. What degree of flexibility has been permitted?

At the outset we eliminate two elements over which the various states are allowed no practical discretion. The Social Security Act compels the adoption of a compulsory system, whether desirable or not, and requires that it be supported primarily, if not exclusively, by direct taxes on employers. The states, therefore, have no other choice in selecting a method "to socialize the losses resulting from unemployment." These alone cut deeply into any flexibility allowed the states, but we pass over them to avoid debate on policies which have created so many differences of opinion.

${ }^{17}$ Of unemployment compensation laws thus far enacted, five require no contributions whatever from employees. In the states where employee contributions are required, none exceed $\mathrm{x} \%$ of wages or $50 \%$ of the contributions required of employers.

${ }^{18}$ See Message of the President of the United States Recommending Legislation on Economic Security, H. Doc. No. 8I, 74th Cong., Ist. Sess. (1935) p. I6. 
Other objections cannot be thus overlooked. The federal tax, as we have observed, is levied on all employers of eight or more employees. Employments exempted from the tax have no bearing here. By imposing the tax on all employers, and by allowing no credits against this tax to employers exempted from paying contributions under state laws, the states, naturally enough, have not provided such exemptions, even though generally admitted to be desirable. For example, we find no provision for exempting new enterprises or establishments on the verge of bankruptcy, and nothing to encourage expansion of employment by employers already in operation. Even more unfortunate, we find totally inadequate treatment of seasonal, casual or part-time workers. True, the Federal Act defines the term employer to include only those employing eight or more individuals on some 20 days in a calendar year, each day being in a different calendar week. ${ }^{18}$ This definition, however, is important only in determining whether an employer has eight or more individuals in his employ. It does not permit a reduction in tax liability on wages paid to part-time workers, and consequently the states have not seen fit to do so because of the federal tax. We assume that it is socially desirable to stimulate any legitimate form of gainful employment. The Federal Social Security Act has certainly not imparted any such encouragement, nor has it permitted the states to do so with respect to these types of employment.

Most states have undertaken to limit benefits to part-time workers by relating the amount of benefits to the actual number of weeks employed. The emphasis here, however, is on seasonal unemployment and the major purpose is to prevent excessive drains on unemployment reserves. Similar concern for the promotion of seasonal, part-time or casual employment has not been reflected because of the universal application of the payroll tax in the Federal Social Security Act.

Perhaps the most severe condemnation directed against the lack of flexibility in our federal-state system arises in connection with the particular type of law which the states in reality are permitted to adopt under the Federal Act. It is generally conceded that conditions of employment, or unemployment, vary in considerable degree in different trades or industries, or even among employers in the same trade or industry. It is also generally conceded, that no single type of unemployment compensation law is suited to these variables, and that flexibility is indispensable in applying the proper form. On this score, the Social Security Act has imposed important limitations on state action.

The theory of diversity is that employers who can stabilize employment; or reduce unemployment to a minimum, should be permitted to benefit from such activities through a lower rate of contributions, or, under some conditions, be temporarily excused from any contributions whatever. Such is the basis of individual employer reserves, guaranteed employment, or agreements to pay a dismissal wage. Under the Social Security Act, adoption of such plans has been so limited with restrictions as to

${ }^{20}$ Social Security Act, supra note 2, tit. IX, $\$ 907$ (a). 
jeopardize their value for experimental purposes in adapting the best form of unemployment compensation to particular needs or conditions. In effect, we have a lack of flexibility no less objectionable than any that could be inflicted in a completely centralized federal system. ${ }^{20}$

In the first place, the Federal Act successfully limits the choice of plans to three types; the pooled fund, separate reserve accounts for single employers or groups of employers, and a form of guaranteed employment. These original restrictions are accomplished in Section 910 of the Act by refusing credits against the federal tax unless the state law authorizing lower rates of contribution complies with certain additional standards prescribed in the law.

Under Section 902, it will be recalled, credits up to 90 per cent of the federal tax are allowed for contributions under approved state laws. It was contemplated, of course, that state contributions would generally be at rates at least as high as the federal payroll tax, so that employers paying such rates could realize the full benefit of the 90 per cent credit allowance. It was also contemplated, however, that employers with low unemployment records might be rewarded by reducing their rates of contribution. Obviously nothing would be gained if a reduction in state contributions would be offset by an increase in federal tax liability, and for that reason no state would allow lower rates unless the plan under which they were allowed complied with the standards in Section gro of the Federal Act. In this manner, therefore, the Social Security Act has succeeded in restricting the freedom of the states to adopt the form of law most fitted to their local needs.

Credit for lower rates of contribution under a scheme of guaranteed employment can be allowed only if the employer "guarantees in advance thirty hours of wages for each of forty calendar weeks ... in twelve months, to all the individuals in his employ in one or more distinct establishments." ${ }^{21}$ Such restrictions practically eliminate the use of guaranteed employment, one of the most important forms of employment stabilization.22

An employer using casual, part-time, or seasonal workers is immediately excluded, for obviously he cannot guarantee forty weeks of employment during the year "to all the individuals in his employ." The necessity of including all employees likewise precludes adoption of such a scheme to cover only workers whose employment, over a period of time, has acquired a fairly certain degree of permanency. Furthermore,

${ }^{20} \mathrm{We}$ do not overlook provisions in laws already enacted authorizing later adoption of a system of merit ratings. This is desirable, but such provisions represent the limits to which state laws as a practical matter are permitted to go under the Social Security Act. Once merit ratings are adopted, flexibility beyond this point is seriously restricted.

${ }^{21}$ Social Security Act, supra note 2, tit. IX, §gro (c) (3) (A).

${ }^{2}$ Four states have made provision for guaranteed employment accounts, but at the time of writing, only one of such laws had been approved by the Social Security Board, viz., Wisconsin. This law permits exclusion of new workers until after twelve weeks of employment. There may be some doubt, notwithstanding $\$ 908$ of the Act, whether the Commissioner of Internal Revenue would be obliged to permit additional credit allowances for contributions under a plan not covering "all employees," even though approved by the Board.

For a discussion of the effect of the Federal Act upon the use of guaranteed employment plans, see Hibbard, Guaranteed Employment Plans, supra, p. 90. 
the necessity of including all employees "in one or more distinct establishments" may be interpreted to mean that the guarantee of employment must cover all establishments of the employer whether or not all are located in the same state.

Equally rigid requirements are imposed on the use of separate reserve accounts for individual employers, and no credit whatever could be allowed against the federal tax to employers permitted to maintain private compensation plans conforming to standards prescribed by state law or to pay unemployment compensation in the form of a dismissal wage. Any of these alternatives has merit in our quest for the stabilization of employment, and yet as a practical matter they are banned in a law which purports to permit flexibility and experimentation in state laws. In contrast, it would be appropriate to compare the rapid development of state workmen's compensation laws in this country, free from any federal stimulant, and reflecting the diversity of needs and conditions in each particular state.

Since the Federal Act assumed the function of prescribing standards to assure sound state unemployment compensation laws, it is a legitimate criticism of the Act that it failed to prescribe certain standards essential to any sound federal-state system inaugurated in this country. The argument that certain problems are difficult of solution is no excuse for failure to exercise the assumed obligation of aiding the states in initiating sound laws. The failure to include certain standards may well lead to a breakdown in the system and, if the answer to these problems was not available, considerable force is given one of the major arguments of employers that we should not embark upon a nationwide system of unemployment compensation without extensive non-partisan study and investigation by some group selected by the government for that purpose. It is our position that the Federal Social Security Act, in purporting to initiate a joint federal-state plan, should have included standards designed to meet the problems of employers who are carrying on business in more than one state, as well as the problems created by employees who perform work in several states.

Our experience with matters of federal and state taxation of business enterprise, and our experience with the jurisdictional problems which have developed under state workmen's compensation laws and the Federal Employers Liability Act should certainly have impressed upon the proponents of a federal-state system of unemployment compensation the necessity for meeting these difficulties at the very outset. ${ }^{23}$ Serious problems are created by the system we have adopted. A very large percentage of industry, trade, and commerce in this country is carried on by enterprises doing business both in interstate commerce and in several states. What should be the liability of an employer who has employees engaged in interstate commerce?

\footnotetext{
* While the problem of extra-territorial application of state workmen's compensation laws is primarily one of conflict of laws, jurisdictional issues of a more fundamental nature may be involved, as suggested in Alaska Packers' Ass'n v. Industrial Comm. of California, 294 U. S. 532 (I934), wherein the Supreme Court said, at p. 540: "The due process clause denies to a state any power to restrict or control the obligation of contracts executed and to be performed without the state, as an attempt to exercise power over a subject matter not within its constitutional jurisdiction. . . . Similarly, a state may not penalize or
} 
To what extent can a single state exercise jurisdiction over employers having no place of business within the state but who do have employees performing work or services within such state? How should an employer be treated with respect to employees performing work over an area comprising several states? Shall the state where contracts of employment are made be permitted to assess contributions on the wages paid such employees even though the work they perform is rendered outside the state? If this should be the rule, what should be the rule of the state where the employee resides, and which presumably would be burdened with the cost of relief in the event of distress due to unemployment? What is the interest of a state where the services are performed, but in which the contract of employment was not made and in which the employee has no residence? Should we adopt a policy under which each state is encouraged to extend the coverage of its law to all employers or employees over whom it can conceivably assert jurisdiction? Under workmen's compensation laws, jurisdiction has been asserted, and sustained, by the state in which the contract of employment is made and also by the state where the injury occurs. ${ }^{24}$ Let us examine efforts to solve these problems in connection with unemployment compensation laws.

The Social Security Act itself contains nothing to guide the states in adopting uniform treatment of these problems. Section 906 of the Act is of no assistance whatever. It provides that:

"No person required under a State law to make payments to an unemployment fund shall be relieved from compliance therewith on the ground that he is engaged in interstate commerce, or that the State. law does not distinguish between employees engaged in interstate commerce and those engaged in intrastate commerce."

This provision is meaningless. If inclusion of certain employers or employees under a state law should burden interstate commerce, there is serious doubt whether Congress could sanction or excuse such burden. If inclusion under workmen's compensation laws is any analogy, the same groups undoubtedly can be embraced within unemployment compensation laws without imposing a burden on interstate commerce. This provision in the Federal Act has merely served as a suggestion to the states to make their own laws all-inclusive. If not this, then its only purpose must be the suggestion of a rule of decision to be followed by the courts.

These problems have been variously treated in state laws, and the solution recommended in the Model Act drafted by the Committee on Economic Security, even though generally adopted, is subject to serious objections. The Model Act recom-

tax a contract entered into and to be performed outside the state, although one of the contracting parties is within the state."

States where the contract of employment is made have extended protection for injuries received elsewhere, Bradford Electric Co. v. Clapper, 286 U. S. I45 (r93I); Alaska Packers' Ass'n v. Industrial Comm., supra. On the other hand, states where the injury oceurs have extended protection of their laws even though contract of employment was made in another state. Ohio v. Chattanooga Boiler \& Tank Co., 289 U. S. 439 (1932).

2 See note 23 , supra. 
mends, and several states have adopted in substance, a provision that an "employee" shall be considered "an employee within the state" when "all or the greater part" of his work is performed within such state.25 The entire annual wage of such persons would be the basis of his employer's contributions. In the case of other persons employed in more than one state, the term "employment" would include "the employment of such persons to the extent prescribed by general rules" to be adopted by each state administrative agency. ${ }^{20}$ What is the effect of this provision?

The entire wage of an employee may be taxed in two or more states to the same extent as could be done without such a provision. Furthermore, this standard fails to consider the real basis of unemployment compensation, but, like other defects in the system we have established, it treats the building up of reserves as another scramble for revenue. In proposing a uniform rule for solution of these problems, it is to be regretted that due consideration could not have been given to some residence requirement to provide for the states which would assume the burden of relief in case of unemployment distress, not to mention relief to employers who ultimately must conform to the conflicting laws and regulations of forty-nine distinct sovereigns. We admit these problems would exist if the states were completely free from federal control in enacting such laws. The Federal Social Security Act, however, provides a joint federal-state system, and it is a legitimate criticism of that law that it fails in this important respect to meet its assumed responsibility.

The problems of administration incident to a federal-state system have necessarily appeared in criticisms we have directed against specific features of the law. These problems cannot be exaggerated. They are inherent in collection of the federal tax, in the functions delegated to the Social Security Board to approve and supervise state laws, as well as in the actual administration of state unemployment compensation. This division of administration among three distinct agencies of government in itself creates additional problems, not to mention the serious tax burden necessary to support the enormous bureaucracy which must be maintained to perform activities which necessarily overlap.

Our major criticism of provisions for administration, however, is on an entirely different basis. We suggest it with the firm conviction that no system, whether federal, state, or a combination of the two, has any chance of success unless every safeguard is established for honest and efficient administration, as far as possible removed from partisan politics. Unfortunately the Federal Social Security Act is barren of any such essential safeguard. The important function of administration under the federal law and supervision over administration of state laws has been vested in the Social Security Board. The personnel of this agency will be selected under the following general grant of authority.

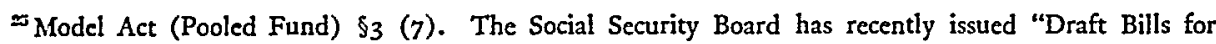
State Unemployment Compensation" in which the provisions relating to territorial coverage are more specific than those contained in the Model Act. See Draft Bill (Pooled Fund) \$rg ( $\mathrm{g}$ ).

The problem of territorial coverage is discussed in Lotwin, Coverage of State Unemployment Compensation Laws, supra, p. 7.

${ }^{20}$ Model Act (Pooled Fund) $\$ 3(7)$. 
"The Board is authorized to appoint and fix the compensation of such officers and employees, and to make such expenditures, as may be necessary for carrying out its functions under this Act. Appointments of attorneys and experts may be made without regard to the civil-service laws."

In the discretion of the Board, attorneys and experts, whatever the latter may include, may be appointed pursuant to the civil-service laws. It is not mandatory with respect to such personnel, nor is it required that other classes of employees be appointed subject to the merit system. Complete freedom, therefore, has in effect been granted to the Social Security Board to establish federal administrative machinery free from the Civil Service law and the Classification Act, and, considering our experience with similar grants of authority to political appointees, our chance for obtaining an efficient and non-partisan administration is remote at best. ${ }^{27}$

State administration has been subjected to the same initial handicap. Federal supervision of state administration is accomplished in Title III of the Social Security Act. Under its provisions, federal funds will be granted to the states for administration of unemployment compensation, if the state law has been approved under Title IX, and approved further with respect to certain administrative requirements prescribed in Section 303 of Title III. The first of these requirements reads as follows:

"Such methods of administration (other than those relating to selection, tenure of office, and compensation of personnel) as are found by the Board to be reasonably calculated to insure full payment of unemployment compensation when due."

As a result of this provision, responsibility for honest, efficient and non-partisan administration has been completely abandoned under conditions where it might legitimately have been included as a requisite to the receipt of federal grants. In criticising this defect, we are not suggesting that the Federal Government should attempt to direct and control the administration of state laws through its own bureaucratic machinery. We do assert, however, that among other requirements imposed as a condition to receiving federal grants, the Social Security Act is seriously defective in not requiring some minimum standard for the selection of personnel on a merit basis. Because of this failure in connection with federal and state administration, we have embarked on a program involving serious social, economic, and political complications with absolutely no assurance of competent administrative machinery.

We have endeavored to present in the few pages allotted to us, some of the major criticisms from the employer's standpoint against the form of unemployment compensation system inaugurated under the Federal Social Security Act. There are, of course, serious questions involving the validity of Title IX of that law, as well as

${ }^{27} \mathrm{CF}$. provisions in the original bills, H. R. 4120, and S. $1130,74^{\text {th }}$ Cong., rst Sess. (1935), requiring appointment of personnel under civil service. 
the validity of state unemployment compensation acts enacted under it. ${ }^{28}$ There are likewise serious financial implications in any law which extends federal control over the investment and liquidation of the tremendous reserves which will be accumulated in the Unemployment Trust Fund in the Federal Treasury. Obviously, limitations upon space preclude the presentation here of criticisms resulting from an analysis of these important aspects. We mention them because they constitute important elements in a complete statement of the employer's viewpoint. If in other respects we have succeeded in clarifying the position of employers, our purpose will have been amply fulfilled.

We have endeavored to clarify some of the more obvious defects in the joint federal-state system of unemployment compensation under Title IX of the Social Security Act. In our opinion it lacks any of the advantages that might inhere in a completely centralized federal plan, and at the same time embodies the major evils of such a system. On the other hand, the present scheme fails to preserve the advantages in a system of independent state laws, and at the same time retains all the defects of diversity. Where standardization would be desirable, diversity is permitted; and where flexibility is essential, rigidity is imposed. The plan is a hybrid and inherits the most undesirable characteristics of the two systems it purports to harmonize.

Undoubtedly the present plan was adopted through fear that a completely centralized federal system was impossible under the Constitution. With this we agree, but on the further and more fundamental ground that the country is too large and industrial conditions too diverse to warrant centralized control. Problems of administration and lack of flexibility would lead to its ultimate collapse. In our opinion the choice between a single federal system and independent state laws has been predetermined by our economic, social and political development. Why then, was the development of a system of unemployment compensation not left to the several states?

Two major reasons have been advanced. First, that the states, if left free, would not take the initiative, primarily through fear of placing their employers at a competitive disadvantage with those of other states, and, second, that the huge reserves to be accumulated presented national financial problems requiring federal control and supervision of the entire fund. Without joining in debate, let us simply point out that over a period of less than fifteen years, beginning around xgIr, all but three industrial states adopted workmen's compensation laws without benefit of federal stimulants, and suggest further that under the new Federal Banking Act of 1935, our Federal Reserve System is adequately equipped to protect our national economy against the most violent deflation that might be set in motion by the liquidation of state unemployment compensation reserves.

* For a discussion of constitutional issues arising under state unemployment compensation laws, see Rice, $A$ Note on the Constitutionality of State Unemployment Compensation Laws, infra, p. 138. [Two articles presenting the cases for and against the constitutionality of the several titles of the Social Security Act will be included in the April issue of this periodical.-Ed.] 